\title{
BLENDED LEARNING DALAM MERDEKA BELAJAR TEKS EKSPOSISI
}

\author{
Fajarika Ramadania ${ }^{1}$ dan Dana Aswadi ${ }^{2}$
}

\author{
Universitas Negeri Surabaya, STKIP PGRI Banjarmasin
}

email: fajarika.19016@mhs.unesa.ac.id,dadan899@yahoo.co.id

\begin{abstract}
ABSTRAK
Keberhasilan proses pembelajaran sangat bergantung kepada model pembelajaran sebagai strategi pembelajaran yang digunakan guru di kelas. Sejauh ini, strategi pembelajaran yang populer di Indonesia adalah pembelajaran berbasis kelas tradisional (klasikal) dengan menggunakan metode ceramah. Penambahan inovasi pembelajaran yang tepat akan menghasilkan kemandirian dan kepercayaan diri siswa yang telah mencoba mengeksplorasi dan mengeksplorasi tidak hanya para guru. Asumsi inilah yang menyebabkan blended learning menjadi pilihan tanpa belajar tidak cukup hanya dengan tatap muka. Tujuan utama dari eksposisi adalah memperluas pandangan dan pengetahuan seseorang. Ekposisi merupakan bentuk retorika yang sering dipergunakan dalam menyampaikan uraian-uraian yang tidak berusaha mempengaruhi orang lain. Pembaca sama sekali tidak dipaksa untuk menerima pendapat penulis. Setiap pembaca memiliki persepsi sendiri, boleh menerima atau menolak tetapi setidaknya pembaca sudah mengetahui bahwa ada orang yang berpendapat demikian. Merdeka belajar dan guru penggerak bukanlah sesuatu yang baru dalam dunia pembelajaran. Setiap anak yang dilahirkan pasti memiliki keistimewaan yang berbeda-beda satu dengan yang lainnya. Disinilah kita sebagai pendidik harus mampu menjadi teman belajar yang menyenangkan agar proses belajar anak benar-benar atas kesadaraannya sendiri dan merdeka atas pilihannya. Diperlukan waktu yang cukup serta kesabaran dalam memfasilitasi, agar anak mampu untuk mengenali potensinya. Karena bakat anak bisa tumbuh ketika anak sudah memiliki minat dan mau berlatih untuk mengasah keterampilannya. Dalam mengawali proses belajar, pendidik juga perlu memiliki kemampuan mendengar yang baik. Tidak hanya sekedar mentransfer pengetahuan dan mendikte anak-anak atas kehendak pendidik.
\end{abstract}

Kata Kunci: metode belajar, blended learning, tekseksposisi, merdeka belajar

\section{PENDAHULUAN}

Keberhasilan proses pembelajaran sangat bergantung kepada model pembelajaran yang digunakan guru karena model pembelajaran memuat rencana yang akan guru lakukan di dalam kelas. Seiring dengan berjalannya waktu dan munculnya berbagai macam inovasi dalam dunia pendidikan maka banyak model-model pembelajaran yang lahir demi terwujudnya tujuan belajar yang baik.

Agar proses pembelajaran dapatberjalan denganbaik, maka seorang guru harus dapat menentukan model pembelajaran yang cocok. Oleh karena itu, pemilihan model harus dilakukan dengan sungguh-sungguh karena dapat menentukan tercapai atau tidaknya sebuah tujuan pembelajaran. Aunurrahman, (2014:140). mengemukakan bahwa model pembelajaran dapat 
diartikan sebagai kerangka konseptual yang melukiskan prosedur yang sistematis dalam mengorganisasikan pengalaman belajar untuk mencapai tujuan belajar tertentu, dan berfungsi sebagai pedoman bagi para perancang pembelajaran dan para guru untuk merencanakan dan melaksanakan aktivitas pembelajaran. Model pembelajaran juga dapat dimaknai sebagai perangkat rencana atau pola yang dapat dipergunakan untuk merancang bahan-bahan pembelajaran serta membimbing aktivitas pembelajaran dikelas atau ditempat lain yang melaksanakan aktivitas pembelajaran.

Pembelajaran saat ini yang sedang digandrungi adalah pembelajaran berbasis teknologi menggunakan internet. Pembelajaran yang menggunakan internet melahirkan sistem pembelajaran yang lebih fleksibel, dapat dilakukan dimana saja dan kapan saja (online learning). Namun, di Indonesia halinibelum dapat dilakukan sepenuhnya karena keterbatasan sarana dan sumber daya untuk melakukan fully online learning. Hal inidikarenakanperlu mempertahankan pertemuan tatap muka dengan mengombinasikan dengan online learning yaitu blended learning, sehingga potensi peserta didik dapat dikembangkan. Oleh sebab itu, agar blended learning dapat diimplementasikan dibutuhkan desain sistem pembelajaran. Sistem terdiri dari banyak bagian yang saling berhubungan satu dengan yang lainnya. Ketika satu komponen tidak berjalan sesuai perannya maka tujuan dari sistem juga akan terganggu, misalnya tujuan pembelajaran, materi, metode dan media, peserta didik, pendidik dan evaluasi. Komponen pembelajaran inilah yang saling melengkapi dalam mencapai tujuan desain sistem pembelajaran yaitu menciptakan suasana belajar yang kondusif agar peserta didik secara optimal mengembangkan potensi diri.

Ketika pembelajaran menjadi inti dari pendidikan, maka pembelajaran pada intinya merupakan perwujudan suasana belajar dalam upaya mengembangkan potensi peserta didik dalam upaya meningkatkan kualitas sumber daya manusia. Transfer pengetahuan akan terjadi dalam proses interaksi sosial antara peserta didik dan pendidik sehingga hasil interaksi pendidikan tersebut akan membentuk tingkah laku yang berpendidikan pula. Cara terbaik dalam membelajarkan itu dengan mencontohkan melalui interaksi antara pendidik dengan peserta didik, bukan sekadar justifikasi. Hal ini sebenarnya juga termaktub dalam UU nomor 20 tahun 2003 [2] tentang Sistem Pendidikan Nasional bahwa pendidikan merupakan usaha sadar dan terencana untuk mewujudkan suasana belajar dan proses pembelajaran agar peserta didik secara aktif mengembangkan potensi dirinya untuk memiliki kekuatan spiritual keagamaan, pengendalian diri, kepribadian, kecerdasan, akhlak mulia serta keterampilan yang diperlukan dirinya, masyarakat, bangsa dan negara. Oleh sebab itu, untuk memecahkan permasalahan pendidikan, tersebut perlu peningkatan kualitas 
pembelajaran melalui sebuah rancangan sistem pembelajaran. Sistem pembelajaran inilah yang membantu pendidik menciptakan pembelajaran berkualitas. Rancangan sistem pembelajaran yang sedang digandrungi saat ini adalah rancangan sistem pembelajaran yang berbasis teknologi karena relevan dan sangat disukai oleh anak-anak usia sekolah.

Kehadiran teknologi komputer dan jaringan di Indonesia, telah mempengaruhi proses belajar di ruang kelas. Dengan munculnya teknologi ini belajar bisa saja dilakukan dimana saja. Jika sebelum teknologi komputer dan jaringan digunakan di Indonesia, orang-orang mengirim modul pembelajaran untuk belajar mandiri dalam bentuk, maka pengoptimalan komputer dan internet dalam pembelajaran dapat mempermudah distribusi modul menggunakan email atau dapat didownload pada website tertentu yang sudah disediakan. Menurut Smaldino (2012: 105), istilah pembelajaran berbasis komputer yang menggunakan jaringan internet disebut dengan online learning. Meskipun online learning menawarkan media yang bervariasi dan fleksibel waktu serta tempat, ternyata pembelajaran ini memiliki kelemahan-kelemahan tertentu (Bersin, 2004:10). Hal ini melahirkan pembelajaran yang mencampurkan pembelajaran online dengan pembelajaran tatap muka yang disebut dengan blended learning. Pencampuran tersebut dengan mengombinasikan kelebihan pertemuan tatap muka dengan kelebihan online learning dan meminimalisir kekurangan pertemuan tatap muka dengan online learning. Berdasarkan perkembangan tersebut, maka saat ini fokus pengembangan sistem pembelajaran adalah sistem pembelajaran yang berbasis blended learning. Sistem pembelajaran blended learning seperti apa yang dapat meningkatkan interaksi pendidikan antara peserta didik dan pendidik dalam upaya mengembangkan potensi peserta didik sehingga ketiga masalah pokok pendidikan di Indonesia terpecahkan.

Pada proses pembelajaran guru bertugas untuk selalu berperan aktif ketika sedang mengajar. Apabila proses pembelajaran berlangsung menyenangkan dan tidak membosankan, maka akan timbul rasa senang belajar. Setelah timbul rasa senang belajar, siswa akan lebih mudah memahami materi yang di sampaikan oleh guru. Begitu juga sebaliknya, apabila guru menyampaikan materi di dalam kelas dengan cara yang membuat siswa jenuh, maka perhatian siswa pun tidak ada. Dan jika perhatian siswa tidak ada, maka materi yang disampaikan oleh guru tidak dapat diterima dengan baik oleh siswa.

Blended Learning merupakan kombinasi antara model pembelajaran tatap muka (face to face) dengan model pembelajaran berbasis e-learning. Model pembelajaran ini memfasilitasi peserta didik selama proses pembelajaran. Dengan menerapkan model Blended Learning, maka akanterjadi perubahan, dimana proses belajar tidak hanya mendengarkan uraian materi dari guru 
tetapi siswa dapat menggunakan fasilitas e-learning yang dapat diakses dimana saja dan kapan saja. Dengan diterapkannya model Blended Learning ini, diharapkan dapat membuat siswa lebih tertarik untuk mengikuti kegiatan belajar di dalam maupun luar kelas.

Teks eksposisi adalah teks yang memberikan informasi kepada pembaca yang diperkuat dengan fakta atau data yang disajikan oleh penulis. Semi (2007:61) mengatakan bahwa hampir semua tulisan-tulisan narasi, dapat digolongkan ke dalam tulisan eksposisi. Sebenarnya, tulisan deskripsi dan argumentasi adalah bagian dari tulisan eksposisi, karena kedua tulisan ini juga memberikan pengetahuan, informasi, dan menjawab pertanyaan apa, mengapa, kapan dan bagaimana. Akan tetapi karena ada sifat khusus yang dimilikinya maka dinamakan deskripsi dan argumentasi.

Penerapan model Blended Learning dalam pembelajaran menulis teks eksposisi adalah pelaksanaan kegiatan pembelajaran menulis yang berkaitan pengorganisasian karangan, penggunaan kalimat efektif, pemilihan kata yang tepat serta penggunaan ejaan yang benar melalui proses yang mengintegrasikan pembelajaran tatap muka dan pembelajaran jarak jauh yang menggunakan sumber belajar online maupun offline dan beragam pilihan komunikasi yang dapat digunakan oleh guru dan siswa. Teks eksposisi dapat dikatakan sebagai teks yang memberikan informasi kepada pembaca yang diperkuat dengan fakta atau data yang disajikan oleh penulis.

Selanjutnya, Merdekabelajaradalah program kebijakan baru Kementerian Pendidikan dan Kebudayaan Republik Indonesia (Kemendikbud RI) yang dicanangkan oleh Menteri Pendidikan dan Kebudayaan RI Kabinet Indonesia Maju, Nadiem Anwar Makarim.Esensi kemerdekaan berpikir, menurut Nadiem, harus didahului oleh para guru sebelum mereka mengajarkannya pada siswa-siswi. Nadiem menyebut, dalam kompetensi guru di level apa pun, tanpa ada proses penerjemahan dari kompetensi dasar dan kurikulum yang ada, maka tidak akan pernah ada pembelajaran yang terjadi.

Pada tahun mendatang, system pengajaran juga akan berubah dari yang awalnya bernuansa di dalam kelas menjadi di luar kelas. Nuansa pembelajaran akan lebih nyaman, karena murid dapat berdiskusi lebih dengan guru, belajar dengan outing class, dan tidak hanya mendengarkan penjelasan guru, tetapi lebih membentuk karakter peserta didik yang berani, mandiri, cerdik dalam bergaul, beradab, sopan, berkompetensi, dan tidak hanya mengandalkan system ranking yang menurut beberapa survey hanya meresahkan anak dan orang tua saja, karena sebenarnya setiap anak memiliki bakat dan kecerdasannya dalam bidang masing-masing. Nantinya, akan terbentuk para pelajar yang siap kerja dan kompeten, serta berbudi luhur di lingkungan masyarakat. 


\section{HASIL DAN PEMBAHASAN}

\section{Blended Learning}

Pembelajaran campuran (blendedlearning) merupan program pendidikan formalyang memungkinkan siswa belajar (paling tidak sebagian) melalui konten dan petunjuk yang disampaikan secara daring (online) dengan kendali mandiri terhadap waktu, tempat, urutan, maupun kecepatan belajar (Staker, 2012:20). Lebih lanjut, John Merrow (2012) menyatakan "blended learning is some mix of traditionalclassroom instraction (which in itself varies considerably) and instraction mediated by technology". Dengan kata lain, pembelajarancampuran atau Blended learning merupakan perpaduan pembelajaran kelas tradisional dengan pembelajaran berbasis teknologi (modern). Pendapat senada juga diungkapkan oleh Annisa (2014: 108) yang menyatakan bahwa blended learning merupakan suatu sistem belajar yang memadukan antara belajar secara face to face (bertatap muka/klasikal) dengan belajar secara online (melalui penggunaan fasilitas/media internet). Berdasarkan paparan para ahli diatas, dapat didefinisikan blenden learning merupakan sebuah strategi belajar mengajar yang bertujuan untuk mencapai tujuan pembelajaran dengan cara memadukan pembelajaran berbasis kelas/ tatap muka dengan pembelajaran berbasisteknologi dan informasi yang dilakukan secaran daring (online).

Kompleksitas permasalasan pendidikan Indonesia untuk dicarikan solusi dan alternatif pemecahannya menjadi tujuankenapa pembelajaran campuran ini dikembangkan. Berbekal pemahaman awal mengenai konsep dasar blended learning, penulis akan mencoba menyajikan kondisi pembelajaran saat ini dengan menghadirkan blended learning sebagai sebuah inovasi dalamdunia pembelajaran di Indonesia untuk mengatasi persoalan- persoalan yang engah di hadapi dewasa ini.

\section{Teks Eksposisi}

Menurut Kosasih (2014:25) teks eksposisi merupakan “Teks yang menyajikan pendapat atau gagasan yang dilihat dari sudut pandang penulisnya dan berfungsi untuk meyakinkan pihak lain bahwa argumen-argumen yang disampaikannya itu benar dan berdasarkan fakta-fakta". Semi (2007:61) menjelaskanCiri-ciri tulisan eksposisi ialah sebagai berikut. a. Tulisan bertujuan memberikan informasi, pengertian dan pengetahuan. b. Tulisan itu bersifat menjawab pertanyaan apa, mengapa, kapan dan bagaimana. c. Disampaikan dengan gaya yang lugas dan menggunakan bahasa baku. d. Umumnya disajikan dengan menggunakan susunan logis. e. Disajikan dengan nada netral tidak memancinng emosi, tidak memihak dan memaksakan sikap penulis kepada pembaca. 
Menurut Kosasih (2014 : 24) berdasarkan fungsi atau tujuan penyampaiannya, eksposisi tergolong ke dalam jenis teks yang argumentatif. Pembaca atau pendengarnya diharapkan mendapatkan pengertian ataupun kesadaran tertentu dari teks tersebut. Tidak sekadar pengetahuan ataupun wawasan baru, tetapi lebih dari itu, yakni berupa perubahan sikap atau sekurang-kurangnya berupa persetujuan atas pernyataan-pernyataan di dalam teks tersebut.

Menurut Kosasih (2014:24) teks eksposisi dibentuk oleh tiga bagian, yakni sebagai berikut. a. Tesis, bagian yang memperkenalkan persoalan, isu, atau pendapat umum yang merangkum keseluruhan isi tulisan. Pendapat tesebut biasanya sudah menjadi kebenaran umum yang tidak terbantahkan lagi. b. Rangkaian argumen, yang berisi sejumlah pendapat dan fakta-fakta yang mendukung tesis. c. Kesimpulan, yang berisi penegasan kembali tesis yang diungkapkan pada bagian awal.

\section{Merdeka Belajar}

Merdeka Belajar perlu memperhatikan aspek Keadilan \& Mutu Pendidikan sebagai Dua Bilah Mata Uang.Merdeka Belajar terkait dengan upaya sekolah dalam menenamkan Lifelong Learning Capacity ( $L L C$ ) sebagai Tema Sentral Revoluasi Industri Ke-4. Merdeka Belajar terkait dengan upaya sekolah dalam menenamkan Lifelong Learning Capacity (LLC) sebagai Tema Sentral Revoluasi Industri Ke-4.1).

1. LLC akan berkembang cepat jika siswa menguasai literasi dan numerasi dasar (basic literacy and Numeracy) (klaus schwab, 2016); aplikasinya melalui literasi dan numerasi digital.

2. Kemampuan Lirerasi dan Numerasi semakin penting artinya dalam lingkungan digital, namun sulit dikembangkan dengan pendekatan pembelajaran konten (mata pelajaran). Diperlukan proses pelatihan terus-menerus selama sekolah, yaitu:

a. Membaca, memahami materi bacaan dengan cepat;

b. Menulis, menuangkan gagasan melalui tulisan sederhana, mudah difahami, dan santun;

c. Menyimak, menangkap isi pembicaraan orang lain secara cepat dan tepat;

d. Menutur, mengungkapkan gagasan secara lisan secara sederhana,l mudah difahami, dan santun;

e. Berhitung, memahami logika angka, bidang dan ruang untuk mempertajam fikiran dalam praktek sehari-hari; dan

f. Dalam lingkungan digital perlu juga dikembangkan mindset digital melalui aplikasi Literasi dan numerasi digital. 
3. Penguasaan numerasi (matematik) dapat mempertajam analisis seseorang terhadap berbagai permasalahan yang terjadi di lingkungan.

Merdeka Belajar diperlukan untuk mengubah Mindset Anak mengenai pelajaran. Perbedaan itu dapat dlihat seperti bagian di bawah ini:

1) Fixed Mindset:

a. Kemampuan yang dimiliki Anak adalah mutlak dan tidak dapat dirubah,

b. Ada pintar ada bodoh yang diukur hanya kemampuan akademik,

c. Kecerdasan diturunkan secara genetik;

d. Prestasi disimbolkan dengan angka (grade).

2) Growth Mindset:

a. Setiap orang mempunyai kapasitas potensial

b. Potensi itu selalu bisa dikembangkan melalui kemampuan berfikir kritis \& kreatif terhadap permasalahan yang nyata

c. Didukung "lifelong learning capacity".

Bentuk kekeliruan Fixed Mindset yang terjadi diantaranya:

1. Menghafal teori atau konsep

2. Belajar terlalu deduktif, (hanya menyampaikan teori \& konsep)

3. Penilaian yang terlalu vertikal (minus horizontal)

4. "Teacher Centered learning” kurang mampu membangkitkan motivasi belajar anak

5. Image yang keliru: Matematika/IPA itu sulit?; Ilmu Sosial itu Hafalan?

6. Kemampuan Literasi tidak dilatih sejak kecil secara optimal

Sekolah sebaiknya diberikan kewenangan untuk membuat menu Pendidikan life skills pilihan perorangan dan sekolah juga harus dan dapat menjamin penyelenggaraannya.

Berikut merupakan contoh teks eksposisi.

Indonesia menjadi buah bibir pada saat pelaksanaan Sidang Tahunan International Monetery Fund (IMF)/World Bank (WB) 2012 Tokyo, 9-14 Oktober 2012 lalu. Newsletter resmi yang dibagikan IMF kepada seluruh peserta sidang mengangkat satu topik khusus mengenai Indonesia. Media itu mengangkat hasil riset dari McKinsey dan Standard Chartered yang mengatakan bahwa 
ekonomi Indonesia akan melampaui Jerman dan Inggris pada tahun 2030. Keyakinan itu tentu beralasan. Indonesia diperkirakan memiliki sekitar 90 juta orang yang berada di kelompok consuming class. Angka ini adalah angka terbesar di dunia setelah Cina dan India. Dengan kekuatan itu pula, pada tahun 2030 Indonesia akan menjadi kekuatan ekonomi nomor tujuh dunia dengan nilai pendapatan nasional sebesar 1,8 triliun dolar AS dari sektor pertanian, konsumsi, dan energi. 17 Indonesia saat ini sedang berada pada laju transformasi yang pesat menuju ke arah tersebut. Saat ini, ekonomi Indonesia berada pada posisi 16 dunia dengan pendapatan domestik nasional sebesar 846 miliar dolar AS tahun 2011. Angka itu akan terus tumbuh hingga mencapai 1,8 triliun dolar AS mulai tahun 2017. Pada tahun 2030 hanya Amerika Serikat, Cina, India, Jepang, Brasil, dan Rusia, yang berada di atas ekonomi Indonesia. Kekuatan terbesar ekonomi Indonesia tidak hanya berupa ekspor yang didukung oleh kekuatan tenaga kerja dan komoditas, tetapi juga kekuatan konsumsi domestik dan jasa-jasa, yang menjadi motor penggerak ekonomi nasional. Melihat potensi yang sedemikian besar, dalam beberapa side meeting siding IMF yang sempat saya ikuti, para investor asing mengharapkan makin banyak pilihan investasi di Indonesia. Harapan para investor tersebut tentu merupakan peluang dan tantangan bagi Indonesia. Upaya melakukan pendalaman pasar keuangan (Financial deepening) menjadi penting dalam memberikan ragam pilihan investasi bagi para investor. Di sisi lain, pembenahan di sektor riil dan infrastruktur perlu terus dilakukan secara serius guna mendukung arah untuk menjadikan ekonomi Indonesia yang terbesar di Asia Tenggara. Saat ini, pertumbuhan ekonomi Indonesia yang berada pada kisaran5 persen hingga 6 persen, apabila dapat terus dipertahankan, akan menambah jumlah masyarakat kelas menengah hingga 90 juta orang dengan pendapatan per kapita lebih dari 3.600 dolar AS. Apabila kita mampu mendorong pertumbuhan hingga 7 persen, jumlah itu bertambah lagi dengan masyarakat menengah mencapai 170 juta orang. Berbagai perkembangan dari sidang akbar IMF di Tokyo pekan lalu kembali mengingatkan kita tentang besarnya potensi Indonesia dan sempitnya momentum yang sedang kita lalui saat ini. Apabila potensi itu tidak diwujudkan dalam aksi dan momentum yang baik dilewatkan begitu saja karena kita begitu asyik dengan urusan lain, prediksi para investor tersebut tidak akan menjadi kenyataan. Tentunya pilihan ada di tangan kita semua saat ini.

Sumber : Bahasa Indonesia Ekspresi Diri dan Akademik : 2014

Pembahasan

1. Pernyataan pendapat (tesis) Indonesia menjadi buah bibir pada saat pelaksanaan Sidang Tahunan International Monetery Fund (IMF)/World Bank (WB) 2012 Tokyo, 9-14 Oktober 2012 lalu. 
Newsletter resmi yang dibagikan IMF pada seluruh peserta sidang mengangkat satu topik khusus mengenai Indonesia. Media itu mengangkat hasil riset dari McKinsey dan Standard Chartered yang mengatakan bahwa ekonomi Indonesia akan melampaui Jerman dan Inggris pada tahun 2030 .

2. Argumentasi Keyakinan itu tentu beralasan. Indonesia diperkirakan memiliki sekitar 90 juta orang yang berada di kelompok consuming class. Angka itu adalah angka terbesar di dunia setelah Cina dan India. Dengan kekuatan itu pula, pada tahun 2030 Indonesia akan menjadi kekuatan ekonomi nomor tujuh dunia dengan nilai pendapatan nasional sebesar 1,8 triliun dolar AS dari sektor pertanian, konsumsi, dan energi. Indonesia saat ini sedang berada pada laju transformasi yang pesat menuju ke arah tersebut. Saat ini, ekonomi Indonesia berada pada posisi 16 dunia dengan pendapatan domestik nasional sebesar 846 miliar dolar AS tahun 2011. Angka itu akan terus tumbuh hingga mencapai 1,8 triliun dolar AS mulai tahun 2017. Pada tahun 2030, hanya Amerika Serikat, Cina, India, Jepang, Brasil, dan Rusia, yang berada di atas ekonomi Indonesia. Kekuatan terbesar ekonomi Indonesia tidak hanya berupa ekspor yang didukung oleh kekuatan tenaga kerja dan komoditas, tetapi juga kekuatan konsumsi domestik dan jasa-jasa, yang menjadi motor penggerak ekonomi nasional. Melihat potensi yang sedemikian besar, dalam beberapa side meeting sidang IMF yang sempat saya ikuti, para investor asing mengharapkan makin banyak pilihan investasi di Indonesia. Harapan para investor tersebut tentu merupakan peluang dan tantangan bagi Indonesia. Upaya melakukan pendalaman pasar keuangan (Financial deepening) menjadi penting dalam memberikan ragam pilihan investasi bagi para investor. Di sisi lain, pembenahan di sektor riil dan infrastruktur perlu terus dilakukan secara serius 19 guna mendukung arah untuk menjadikan ekonomi Indonesia yang terbesar di Asia Tenggara. Saat ini, pertumbuhan ekonomi Indonesia yang berada pada kisaran 5 persen hingga 6 persen, apabila dapat terus dipertahankan, akan menambah jumlah masyarakat kelas menengah hingga 90 juta orang dengan pendapatan per kapita lebih dari 3600 dolar AS. Apabila kita mampu mendorong pertumbuhan hingga 7 persen, jumlah itu bertambah lagi dengan masyarakat menengah mencapai 170 juta orang.

3. Penegasan ulang pendapat Berbagai perkembangan dari sidang akbar IMF di Tokyo pekan lalu kembali mengingatkan kita tentang besarnya potensi Indonesia dan sempitnya momentum yang sedang kita lalui saat ini. Apabila potensi itu tidak diwujudkan dalam aksi dan momentum yang baik dilewatkan begitu saja karena kita begitu asyik dengan urusan lain, prediksi para investor tersebut tidak akan menjadi kenyataan. Tentunya pilihan ada di tangan kita semua saat ini. 


\section{SIMPULAN}

Kesimpulan dari Blended Learning Merdeka Belajar Teks Eksposisi diantaranya:

1. Penerapan model Blended Learning dalam pembelajaran menulis teks eksposisi adalah pelaksanaan kegiatan pembelajaran menulis yang berkaitan pengorganisasian karangan,penggunaan kalimat efektif, pemilihan kata yang tepat serta penggunaan ejaan yang benar melalui proses yang mengintegrasikan pembelajaran tatap muka dan pembelajaran jarak jauh yang menggunakan sumber belajar online maupun offline dan beragam pilihan komunikasi yang dapat digunakan oleh guru dan siswa.

2. Teks eksposisi dapat dikatakan sebagai teks yang memberikan informasi kepada pembaca yang diperkuat dengan fakta atau data yang disajikan oleh penulis.

3. Kemampuan menulis teks eksposisi dalam menulis karangan eksposisi dengan kualitas yang maksimal dilihat dari kemampuan dalam mengorganisasikan karangan, penggunaan kalimat efektif, pemilihan kata yang tepat serta penggunaan ejaan yang benar.

4. Menulis karangan eksposisi merupakan salah satu bagian kompetensi dasar dari pembelajaran bahasa dan sastra Indonesia yang terdapat dalam kurikulum 2013.

5. Pembelajaran online dapat dilakukan oleh siapa saja, kapan saja, dan dimana saja selama dapat mengakses internet.

Apapun bentuk strategi, metode ataupun model pembelajaran yang diterapkan dan dimanfaatkan dengan baik dan tepat di dalam pendidikan akan memperluas kesempatan belajar, meningkatkan efisiensi, meningkatkan kualitas pembelajaran, memfasilitasi pembentukan keterampilan, dan mendorong belajar sepanjang hayat secara berkelanjutan seperti yang disampaikan pada awal tulisan ini. Blended learning bukanlah satu- satunya alternatif dalam mengatasi permasalahan pembelajaran. Namun di tengah pesatnya arus informasi dan komunikasi diberbagai lapisan masyarakat, menjadikan blended learning solusi esensial masa kini.

Pembelajaran campuran atau blendedlearning merupakan sebuah strategi belajarmengajar yang bertujuan untuk mencapai tujuan pembelajaran dengan cara memadukan pembelajaran berbasis kelas/tatap muka dengan pembelajaran berbasis teknologi dan informasi yang dilakukan secaran daring (online). Selama ini strategi pembelajaran yang populer di Indonesia adalah pembelajaran tradisional berbasis kelas (klasikal) dengan menggunakan metode ceramah. Penambahan inovasi pembelajaran yang tepat akan membangkitkan kemandirian serta percaya diri siswa yang telah berusaha mencari dan mengeksplorasi sumber belajar tidak hanya dari guru saja.Asumsi inilah yang mengantarkan blended learning menjadi sebuah pilihan ketika belajar tidak cukup hanya dengan tatap muka. 


\section{DAFTAR RUJUKAN}

Aunurrahman. 2013. Belajar dan Pembelajaran. Bandung: Alfabeta.

Bersin, J. 2004. The Blended Learning Book; Best Practices, Proven Methodologies and Lessons Learned. United Stated: John Wiley \& Sona, Inc.

Dwiyogo, W. D. 2013. Pembelajaran Berbasis Blanded Learning. Tersedia pada: http://www.id.m.wikibooks.org/wiki/ Pembelajaran_Berbasis_Blended_Learning. Diakses pada Minggu, 20 Maret 2020.

Harel, C., I. 2012. Learning to Make Games for Impact. The journal pf MediaLiteracy, 59(1), 28- 38.

Husamah. 2014. Pembelajaran Bauran (Blended Learning). Jakarta; Prestasi Pustaka.

Kirna, I. M. 2013. Penerapan Strategi Problem Posing Yang Disampaikan Secara Blended Learning Pada Perkuliahan Chemical Bonding. Seminar Nasional FMIPA UNDIKSHA III Tahun 2013.

Kosasih. 2014. Strategi Belajar dan Pembelajaran. Bandung: Yrama Widya.

Ratna, S. A. 2013. Strategi Blended Learning Untuk Peningkatan Kemandirian Belajar Dan Kemampuan Critical Thinking Mahasiswa Di Era Digital. JurnalPendidikan Akuntansi Indonesia, Vol. XI, No. 2, Tahun 2013.

. 2014. Peningkatan Prestasi BelajarDan Kemampuan Group-Work Melalui Kombinasi Pembelajaran Peer Learning Dan Blended Learning. Jurnal PendidikanAkuntansi Indonesia, Vol. XII, No. 1, Tahun 2014.

Sandi, G. 2012. Pengaruh Blended Learning Terhadap Hasil Belajar Kimia Ditinjau Dari Kemandirian Siswa. Jurnal Pendidikan dan Pengajaran, Jilid 45, Nomor 3, Oktober 2012.

Semi, A. 2007. Dasar- Dasar Keterampilan Menulis. Bandung: Angkasa.

Smaldino, S. E., Lowther, D. L. dan Russel, J. D. 2012. Instructional Technology and Media for Learning. Boston: Allyn \& Bacon.

Staker, H., H, M.B. 2012 Classifying K-12 Blended Learning. Innosight Institute.

Suastika, I. N. 2015. Perspektif Global: Implikasi Globalisasi dalam Dunia Pendidikan. Disampaikan pada perkuliahan Perspektif Global Jurusan Pendidikan Dasar Program Pascasarjana Universitas Pendidikan Ganesha pada Minggu, 20 Desember 2015.

Susila, D. I. P. 2015. ICT: Suplemen Untuk Meningkatkan Kualitas Pembelajaran dan Computer Literacy.Simposium Guru dan Tenaga.

Watson, J. 2008. Blended Learning:The Convergence of Online and Face-toFace Education. iNACOL Promising Pravtices in Online Learning. 
Yusuf, H. M. 2011. Menuai Benih Teknologi Pendidikan. Jakarta: Kencana. 